\title{
The Effect of Sodium Hydroxide or Dithiothreitol-Urea on Spores of Germination Mutants of Clostridium bifermentans
}

\author{
By LINDA R. WYATT AND W. M. WAITES \\ Agricultural Research Council Food Research Institute, \\ Colney Lane, Norwich NOR $70 F$
}

(Received 3 September 1973; revised 9 April 1974)

INTRODUCTION

Wax, Freese \& Cashel (1967), Vary \& Kornberg (1970), Dring \& Gould (197I) and Foerster (1972) have isolated mutants of Bacillus which germinate more slowly than the wild type. We have isolated slow germination mutants from an anaerobe, Clostridium bifermentans, and have shown that treatment with sodium hydroxide will increase their germination rates over 1000-fold to rates similar to those of the parent (Wyatt \& Waites, 1971). Dithiothreitol-urea, like sodium hydroxide, removes protein from spore coats (Aronson \& FitzJames, 1971 ; Waites, Wyatt \& Arthur, 1972). We report the effect of sodium hydroxide or dithiothreitol-urea on these mutants.

\section{METHODS}

The parent strain of Clostridium bifermentans, mutants I, 3, 4 and 5 derived from it, and the preparation of spores were as described by Wyatt \& Waites (197I). Mutant 6 was isolated by the same procedure, using L-alanine. Treatment of spores with sodium hydroxide was either at $4^{\circ} \mathrm{C}$ as described previously (Waites et al. 1972) or at $37^{\circ} \mathrm{C}$. For treatment with $5 \mathrm{~mm}$-dithiothreitol in $4 \mathrm{M}$-urea, $\mathrm{pH} 10.3$, spores (about $700 \mu \mathrm{g} \mathrm{dry} \mathrm{wt} / \mathrm{ml}$ ) were incubated for $90 \mathrm{~min}$ at $37^{\circ} \mathrm{C}$ as described by Aronson \& Fitz-James (197I).

Germination rates were measured at $37^{\circ} \mathrm{C}$ either spectrophotometrically or microscopically as described by Waites \& Wyatt (1971). Results are expressed as the maximum rate of decrease in $E_{600}$ calculated as a percentage of the initial extinction. The microscopic method was used when the germination rate was less than 0.2 and the rates calculated as described by Wyatt \& Waites (197I). Germination systems were (mM): L-alanine (50) plus L-phenylalanine (5) plus L-arginine (5) plus L-lactate (25) (the 'Ala +' system), or L-alanine (50) (the 'Ala' system). Sodium chloride (I00 mM) and sodium phosphate ( $83 \mathrm{~mm}$ ), $\mathrm{pH} 7.5$ (with the 'Ala +' system) or pH 8.0 (with the 'Ala' system), were added.

\section{RESULTS}

\section{Effect of sodium hydroxide on optimum conditions for germination}

Differences were observed between wild type and some mutants with respect to the effect of temperature and $\mathrm{pH}$ on germination rates. For example, with the 'Ala' system, spores of the wild type germinated optimally at $37^{\circ} \mathrm{C}$ (Waites \& Wyatt, I974a) but those of mutant I germinated ten times more rapidly at $25^{\circ} \mathrm{C}$ than at $37^{\circ} \mathrm{C}$. Pretreatment with sodium hydroxide at $4{ }^{\circ} \mathrm{C}$ caused the spores of both strains to germinate more rapidly, with an optimum at about $50^{\circ} \mathrm{C}$. Attempts to extend these findings to the other mutants were frustrated by their 
Table I. Effects of sodium hydoxide and dithiothreitol-urea on the germination rates $(\% / \mathrm{min})$ of spores of the wild type and mutants

\begin{abstract}
Spore suspensions were treated as described in Methods before germinating with the "Ala+' system or with lysozyme ( $100 \mu \mathrm{g} / \mathrm{ml})$ plus sodium phosphate $(\mathrm{pH} 7 \cdot 0,83 \mathrm{~mm})$. Germination was followed microscopically (when the rate was less than 0.2 ) or spectrophotometrically.
\end{abstract}

\begin{tabular}{|c|c|c|c|c|}
\hline Strain & Untreated & $\begin{array}{l}\text { Sodium } \\
\text { hydroxide } \\
\text { at } 4^{\circ} \mathrm{C}\end{array}$ & $\begin{array}{c}\text { Sodium } \\
\text { hydroxide } \\
\text { at } 37^{\circ} \mathrm{C}\end{array}$ & Dithiothreitol-ur \\
\hline \multicolumn{5}{|c|}{ With 'Ala +' system } \\
\hline Wild type & 58 & 17 & $\mathrm{I} \cdot 8$ & $<\mathrm{I} \times 10^{-3}$ \\
\hline Mutant 4 & 15 & 37 & 0.8 & $<\mathrm{I} \times 10^{-3}$ \\
\hline Mutant 5 & 12 & 30 & 0.09 & $<\mathrm{I} \times 10^{-3}$ \\
\hline Mutant I & $2 \cdot 9$ & 30 & 20 & $<\mathrm{I} \times 10^{-3}$ \\
\hline Mutant 3 & 0.8 & $2 \cdot 0$ & 0.5 & $<\mathrm{I} \times 10^{-3}$ \\
\hline Mutant 6 & 0.3 & $1 \cdot 6$ & 0.09 & $<\mathrm{I} \times 10^{-3}$ \\
\hline \multicolumn{5}{|c|}{ With lysozyme } \\
\hline Wild type & $7 \times 10^{-3}$ & $6 \times 10^{-2}$ & $9 \times 10^{-1}$ & 15 \\
\hline Mutant 4 & $8 \times 10^{-3}$ & $<\mathrm{I} \times 10^{-3}$ & $I \cdot 5$ & 18 \\
\hline Mutant 5 & $9 \times 10^{-3}$ & $2 \times 10^{-3}$ & $4 \times 10^{-1}$ & 27 \\
\hline Mutant I & $<1 \times 10^{-3}$ & $<\mathrm{I} \times 10^{-8}$ & $7 \times 10^{-3}$ & I0 \\
\hline Mutant 3 & $<\mathrm{I} \times 10^{-3}$ & $<\mathrm{I} \times 10^{-3}$ & $5 \times 10^{-2}$ & 26 \\
\hline Mutant 6 & $<\mathrm{I} \times 10^{-3}$ & $<\mathrm{I} \times 10^{-3}$ & $9 \times 10^{-2}$ & 28 \\
\hline
\end{tabular}

very slow germination rates; with the 'Ala +' system, which initiated more rapid germination, no differences were observed in their response to temperature changes.

With the 'Ala + ' system, spores of the wild type germinated most rapidly at about $\mathrm{pH} 7 \cdot 3$ (Waites \& Wyatt, 1974a) but spores of the mutants germinated at least as rapidly between $\mathrm{pH} 6.0$ and 6.5 as at 7.3 . Pretreatment of spores with sodium hydroxide at $4{ }^{\circ} \mathrm{C}$ did not alter the behaviour of the wild type with respect to $\mathrm{pH}$ but brought the optimum of the mutants to that of the wild type. For example, the germination rates of mutant 5 were altered from 15 at $\mathrm{pH} 6.5$ and 3.5 at $\mathrm{pH} 7 \cdot 3$ to 52 and 60 , respectively, by treatment with sodium hydroxide.

\title{
Resistance of spores to heat, sodium hydroxide and dithiothreitol-urea
}

Heating at $75{ }^{\circ} \mathrm{C}$ for Io min, as described by Waites \& Wyatt (1974b), failed to activate spores of either the wild type or mutant $\mathrm{I}$ and decreased their germination rates with the 'Ala +' system from 58 to 6.6 and from $2 \cdot 9$ to $\mathrm{I} \cdot 6$, respectively. With the 'Ala +' system, sodium hydroxide at $4{ }^{\circ} \mathrm{C}$ increased the germination rate of the mutants but decreased that of the wild type (Table I). Sodium hydroxide at $37^{\circ} \mathrm{C}$ increased the germination rate of mutant $I$ but decreased those of the other strains. Treatment with dithiothreitol-urea, which removes coats from spores of Bacillus megetarium (Aronson \& Fitz-James, 197I), reduced the germination rate of all strains. Since treatments which remove protein from spore coats allow lysozyme to attack the spore cortex and bring about germination-like changes (Gould \& Hitchins, 1963), we examined the effect of lysozyme on the spores before and after treatment with sodium hydroxide or dithiothreitol-urea. The wild type and mutants 4 and 5, which germinated more rapidly with the 'Ala +' system, germinated very slowly with lysozyme before treatment; the other three mutants did not germinate. Sodium hydroxide at $4{ }^{\circ} \mathrm{C}$ slightly increased the germination rate of the wild type but not of the mutants, while sodium hydroxide at $37^{\circ} \mathrm{C}$ made all the strains germinate slowly. Treatment with dithiothreitol-urea resulted in rapid germination of all strains, which suggested that any difference in the rate of germination with lysozyme was not due to differences in cortical structure. 
The structure of untreated spores of mutants I, 5 and 6 on examination of ultra-thin sections by electron microscope appeared similar to that of the wild type which has been described (Waites et al. 1972).

\section{DISCUSSION}

In this study we have shown that differences in $\mathrm{pH}$ and temperature optima for germination of the wild-type strain of Clostridium bifermentans and of mutants derived from it are eradicated by treatment of the spores with sodium hydroxide. We have previously suggested that sodium hydroxide increases the permeability of the spores to germinants, perhaps by removing a protein from the spore coat (Wyatt \& Waites, 197I ; Waites et al. 1972). Treatment with urea-mercaptoethanol and sodium hydroxide, or with dithiothreitol-urea, has also been shown to remove coat proteins from spores of bacilli and clostridia (Gould, Stubbs \& King, I970; Aronson \& Fitz-James, 197I) but such treatments sometimes result in slow germination (Hashimoto, Frieben \& Conti, 1972; Vary, 1973). We have shown that the effect of sodium hydroxide treatment is not limited to a particular germinant system; germination rates were accelerated irrespective of the germinants present (Wyatt \& Waites, I97I). These results are consistent with the alteration of a non-specific character such as permeability. Since extracted spore-coat protein is insoluble at neutral $\mathrm{pH}$ but soluble in alkali (Gould et al. 1970 ), the coat structure of spores may differ at different $\mathrm{pH}$ values. Such differences, which might also occur at different temperatures, might result in altered permeability to germinants and so in different germination rates at different $\mathrm{pH}$ values and temperatures. The six strains studied here responded differently to sodium hydroxide, germinants and lysozyme. For example, with the 'Ala +' system, the germination rate of the wild type was decreased by treatment with sodium hydroxide at $4{ }^{\circ} \mathrm{C}$ while those of the mutants were increased; similarly, with lysozyme, untreated spores of the wild type and the two faster germinating mutants germinated slowly while those of the other mutants only germinated after treatment with sodium hydroxide at $37^{\circ} \mathrm{C}$. Usually, germination with lysozyme only occurs after treatment with agents which alter spore coat structure sufficiently to make it permeable to lysozyme (Gould et al. 1970; Aronson \& Fitz-James, I97I ; Cassier \& Ryter, 1971). In our work, differences in germination characteristics were removed by agents which alter the structure of spore coats. It is possible, therefore, that such differences were caused by differences in spore coat structure.

We have also found that the germination mechanism of these slow germination mutants is more resistant than that of the wild type to sodium hypochlorite (Wyatt \& Waites, 1973). Hersom \& Hulland (1963) have reported that some spores which survive heat treatment form colonies only after a lag. This dormancy may be induced by heating; alternatively it is possible that super-dormant spores possess extra resistance to sterilizing procedures, are more difficult to sterilize and are therefore selected by heat treatment.

We are grateful to Dr J. L. Peel for useful discussions and to Miss J. E. Maskell for skilled technical assistance.

\section{REFERENCES}

Aronson, A. I. \& Fitz-JAmes, P. C. (I971). Reconstitution of bacterial spore coat layers in vitro. Journal of Bacteriology 108, 571-578.

CAssier, M. \& Ryter, A. (197I). Sur un mutant de Clostridium perfringens donnant des spores sans tuniques a germination lysozyme-dépendante. Annales de l'Institut Pasteur 121, 717-732.

DRING, G. J. \& GoulD, G. W. (I97I). Movement of potassium during L-alanine-initiated germination of Bacillus subtilis spores. In Spore Research-1971, pp. 133-141. Edited by A. N. Barker, G. W. Gould and J. Wolf. London: Academic Press. 
FOERSTER, H. F. (1972). Spore pool glutamic acid as a metabolite in germination. Journal of Bacteriology IIr, 437-442.

Gould, G. W. \& Hitchins, A. D. (I963). Sensitization of bacterial spores to lysozyme and to hydrogen peroxide with agents which rupture disulphide bonds. Journal of General Microbiology 33, 4I 3-423.

GouLD, G. W., STUBbs, J. M. \& KING, W. L. (1970). Structure and composition of resistant layers in bacterial spore coats. Journal of General Microbiology 60, 347-355.

Hashimoto, T., Frieben, W. R. \& ConTI, S. F. (1972). Kinetics of germination of heat-injured Bacillus cereus sp ores. In Spores V, pp. 409-415. Edited by H. O. Halvorson, R. Hanson and L. L. Campbell. Washington, D.C.: American Society for Microbiology.

Hersom, A. C. \& Hulland, E. D. (1963). In Canned Foods: An Introduction to Their Microbiology. London: J. A. Churchill.

VARY, J. C. (1973). Germination of Bacillus megaterium spores after various extraction procedures. Journal of Bacteriology Ir6, 797-802.

VARY, J. C. \& KornBerg, A. (1970). Biochemical studies of bacterial sporulation and germination. XXI. Temperature-sensitive mutants for initiation of germination. Journal of Bacteriology 1or, 327-329.

WAITES, W. M. \& WYATT, L. R. (1971). Germination of spores of Clostridium bifermentans by certain amino acids, lactate and pyruvate in the presence of sodium or potassium ions. Journal of General Microbiology 67, $215-222$.

WAITES, W. M. \& WyATt, L. R. (1974a). The effect of $\mathrm{pH}$, germinants and temperature on the germination of spores of Clostridium bifermentans. Journal of General Microbiology 80, 253-258.

WAITES, W. M. \& WYATT, L. R. (1974b). The outgrowth of spores of Clostridium bifermentans. Journal of General Microbiology 84, 235-244.

Waites, W. M., Wyatt, L. R. \& ARTHUR, B. (1972). Effect of alkali treatment on the germination and morphology of spores of Clostridium bifermentans. In Spores V, pp. 430-436. Edited by H. O. Halvorson, R. Hanson and L. L. Campbell. Washington, D.C.: American Society for Microbiology.

WAX, R., Freese, E. \& CASHEL, M. (1967). Separation of two functional roles of L-alanine in the initiation of Bacillus subtilis spore germination. Journal of Bacteriology 94, 522-529.

WyatT, L. R. \& WaITES, W. M. (1971). Studies with spores of Clostridium bifermentans: comparison of germination mutants. In Spore Research-1971, pp. 123-13I. Edited by A. N. Barker, G. W. Gould and J. Wolf. London: Academic Press.

WyATT, L. R. \& WAITES, W. M. (1973). The effect of hypochlorite on the germination of spores of Clostridium bifermentans. Journal of General Microbiology 78, 383-385. 